7-31-2018

\title{
Self-organization and crop insurance to enhance livelihood resilience: A case of rice farmers in Cirebon Regency, Indonesia
}

\author{
Nila Pratiwi \\ Universitas Indonesia, Urban and Regional Development Institute (URDI), nila.ahp@gmail.com \\ Mahawan Karuniasa \\ School of Environmental Science, Universitas Indonesia
}

See next page for additional authors

Follow this and additional works at: https://scholarhub.ui.ac.id/ajce

Part of the Social and Behavioral Sciences Commons

\section{Recommended Citation}

Pratiwi, Nila; Karuniasa, Mahawan; and Suroso, Djoko (2018). Self-organization and crop insurance to enhance livelihood resilience: A case of rice farmers in Cirebon Regency, Indonesia. ASEAN Journal of Community Engagement, 2(1).

Available at: https://doi.org/10.7454/ajce.v2i1.116

Creative Commons License

(c) (i) ()

This work is licensed under a Creative Commons Attribution-Share Alike 4.0 License.

This Research Article is brought to you for free and open access by the Universitas Indonesia at ASEAN Journal of Community Engagement. It has been accepted for inclusion in ASEAN Journal of Community Engagement. 


\title{
Self-organization and crop insurance to enhance livelihood resilience: A case of rice farmers in Cirebon Regency, Indonesia
}

\author{
Nila Ardhyarini H. Pratiwiab*, Mahawan Karuniasab, Djoko S. A. Surosoc \\ ${ }^{a}$ Urban and Regional Development Institute (URDI), Indonesia

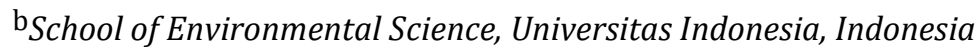 \\ ${ }^{\mathrm{c} S c h o o l ~ o f ~ A r c h i t e c t u r e, ~ P l a n n i n g ~ a n d ~ P o l i c y ~ D e v e l o p m e n t, ~ B a n d u n g ~ I n s t i t u t e ~ o f ~ T e c h n o l o g y, ~ I n d o n e s i a ~}$
}

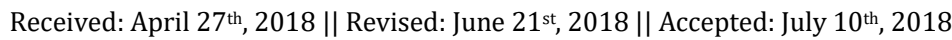

\begin{abstract}
Climate variability and change that affects extreme weather events has resulted in long dry season and drought in Indonesia. Farmers become a vulnerable group since drought has damaged rice fields, making them lose their income. Therefore, rice farmers' livelihood resilience needs to be enhanced in order to cope with those impacts. Crop insurance as financial capital could contribute to famers' income stability against drought. Moreover, self-organization helps the farmers understand agricultural risks and increase their adaptive capacity in times of extreme weather events. Accordingly, this paper investigates the impact of drought on rice production and farmers' income, by analyzing the benefits of crop insurance and the support of selforganization to enhance livelihood resilience with a case of Kapetakan Sub-district in Cirebon Regency, Indonesia. The study employed mixed-methods by combining qualitative and quantitative data based on official data from government, in-depth interview, and literature review. The study reveals drought, for instance El Nino's drought in 2015, has resulted in lower rice production and farmers' income compared to 2014. Crop insurance could increase farmers' income as compensation due to drought, yet, there have been many farmers who do not have crop insurance. Moreover, self-organization related to the network capacity of farmers tends to be limited within farmer groups at village level. The government or other stakeholders should assist in expanding the network of farmers to enable them to interact and learn with other organizations outside the region. Thus, knowledge and skills of farmers which include benefits of crop insurance and how to manage it will increase by being able to choose adaptation option. This condition will contribute to the enhancement of farmers' livelihood resilience to recover from extreme weather events.
\end{abstract}

Keywords: climate change, drought, self-organization, crop insurance, livelihood resilience

\section{Introduction}

Climate change causes changes to the hydrological cycle and affects the occurrence of extreme weather that results in natural disasters (IPCC, 2012). In Indonesia, more than 78\% of natural disasters in 2005-2015 were categorized as climate-related disasters, including drought (BNPB, 2016a). Drought also occurrs because of El Nino, a short-term climate variability that characterized by rising sea surface temperatures along the equatorial Pacific Ocean and its impact affects global circulations patterns (UNDP Indonesia, 2007; Bhuvaneswari et al., 2013; Capa-Morocho et al., 2014). Farmland that is damaged by drought can not be planted with food crops. In Indonesia, many agricultural areas are susceptible and have crop failure due to drought, especially rice crops (BAPPENAS, 2010, Irawan, 2013). For instance, the impact of El Nino on rice crops has caused the average harvested area to decrease by $3.83 \%$ and production decrease by 3.99\% (Setiyanto dan Irawan, 2013).

Extreme weather events have a negative impact on agricultural productivity and rural livelihoods (Shah et al. 2013; Abid et al., 2016a; Khayyati and Aazami, 2016; Khanal et al.,

*Correspondence Author: nila.ahp@gmail.com 
2018). The climate change vulnerability at agricultural level ultimately resulting loss of farmers' income (Abid et al., 2016a; Pratiwi et al., 2016; Rahut and Ali, 2017). The main challenge is that farmers have low adaptive capacity (Abid et al., 2016b; Tripathi and Mishra, 2017), because most of them are small and marginal farmers (Tripathi and Mishra, 2017).

Cirebon Regency is one of the rice barns in West Java Province, thus this region still depends on an agricultural economy. However, climate change impacts could influence the long dry season and resulting in drought events. According to Pratiwi et al. (2016), agricultural land in Cirebon Regency is threatened by drought, which could affect up to 185,075 farmers, including Kapetakan Sub-district. The livelihoods in Kapetakan depend heavily on agricultural land, so any long dry seasons will disrupt the rice planting season and reduce farmers' income. Therefore, rice farmers in this area are a vulnerable group to extreme weather events.

In order to reduce vulnerability of farmers' livelihood, increasing resilience becomes indispensable. Livelihood resilience is a factor and process that keeps livelihood functioning despite changes and increases adaptive capacity to cope with stresses and shocks (Speranza et al., 2014). Furthermore, Speranza et al. (2014) argue that resilience can be maintained if buffer capacity (livelihood assets) is present and does not decrease, self-organization exists and is promoted, and learning takes place. Unfortunately, some farmers in Indonesia do not have sufficient capacity to respond to the impact of drought that causes crop failure and loss of income.

Financial capital becomes one of the buffer capacity that can strengthen resilience, but not easily owned by smallholder farmers. Financial capital is the financial resources that people use to achieve their livelihood goals, including income, savings and access to credit (DFID, 1999; Brocklesby dan Fisher, 2003; Elasha et al., 2005; Reed et al., 2013; Speranza et al., 2014; Keshavarz et al., 2017). Elasha et al. (2005) argue that income stability becomes a reflection to assess community resilience. Regarding to that, crop insurance can be one of the financial capitals to secure the income stability of farmers from extreme weather events. Lunt et al. (2016) argue that crop insurance has a strong position to expand recognition of agricultural climate risks to communities and offer tools to take into account more systematic risks and uncertainties.

Most countries recognize that crop insurance is an important instrument to help farmers manage the financial impact of production risks, mainly because of unpredictable weather, pests and diseases (Dick and Wang, 2010). Application of crop insurance has provided benefits for farmers. In China, crop insurance is considered to have improved the welfare of farmers (Ke et al., 2015). Crop insurance in Philippines also greatly helps vulnerable farmers to reduce financial risk in extreme weather events (Pulhin et al, 2017). In addition, farmers in India argue that agricultural insurance has a positive impact on their livelihoods and is helpful for their recovery from crop losses (Solomon et al., 2017). Furthermore, farmers in Japan also found that crop insurance was useful and beneficial because they received compensation for the recovery from disaster (Nakamura et al., 2017).

Indeed, crop insurance is an important risk mitigation mechanism in agriculture, but its role as revenue security has not been realized by smallholder farmers (Farzaneh et al., 2017). Based on Kapetakan Sub-district officer's explanation, about 60\% rice farmers have joined crop insurance in 2017. In order to ensure the benefits of crop insurance on farmers' income security, the condition of self-organization is crucial. Milestad (2003) defines selforganization in agricultural system as the ability of agricultural groups to form flexible 
Nila A. H. Pratiwi, Mahawan Karuniasa, Djoko S. A. Suroso | ASEAN Journal of Community Engagement | Volume 2, Number 1, 2018

networks and to engage with social, economic and environmental organizations on a scale other than local. Self-organization tends to be robust and can resist disturbance due to its distributed character (Heylighen, 2001), in addition to a flexible and large network. Euler and Heldt (2018) argue that the high degree of self-organization can lead to increased alternative perspectives in dealing with disturbance. Furthermore, farmers with larger networks have more opportunities to assess information and exchange knowledge so that their ability can be more effective (Utaranakorn and Yasunobu, 2016). Hence, strengthening self-organization contributes to improved farmers' knowledge of crop insurance and how to manage it in dealing with drought impacts.

This paper aims to (i) investigate the impact of drought on rice production and farmers' income; (ii) analyze the benefits of crop insurance to enhance livelihood resilience; and (iii) analyze the support of self-organization to enhance livelihood resilience. Cirebon Regency is chosen as the study area because this region has a role as the rice granary of West Java Province but is very vulnerable to extreme weather events, including drought.

\section{Method}

\subsection{The Study Area}

This study was conducted in coastal area of Cirebon Regency located in north coast of West Java Province. The coastal area of Cirebon is 50,720 ha (51.2\% of the total area of Cirebon) with a rice field area of approximately 32,200 ha (63.5\% of the area of coastal area in Cirebon) (Fig. 1). Zikra et al. (2015) argue that the impacts of climate change have a tendency to exacerbate many of the existing problems on the coast. Based on Vulnerability Index Data Information System, the drought risk of Cirebon is at moderate level (KLHK, 2017). Drought has threatened coastal areas of Cirebon and reduced rice production.

Kapetakan Sub-district that located in the coastal area is one of the agriculture contributors to Cirebon nonetheless is included as a drought-affected area. In this study area, there are 3,000 ha of rice fields (50.2\% of the total area of Kapetakan) and more than 7,500 farm households (50\% of the total of households in Kapetakan) (BPS, 2014). Agricultural activities in this area become the main source of community livelihood. Therefore, the rice farmers' livelihood is vulnerable to drought. 
Nila A. H. Pratiwi, Mahawan Karuniasa, Djoko S. A. Suroso | ASEAN Journal of Community Engagement | Volume 2, Number 1, 2018

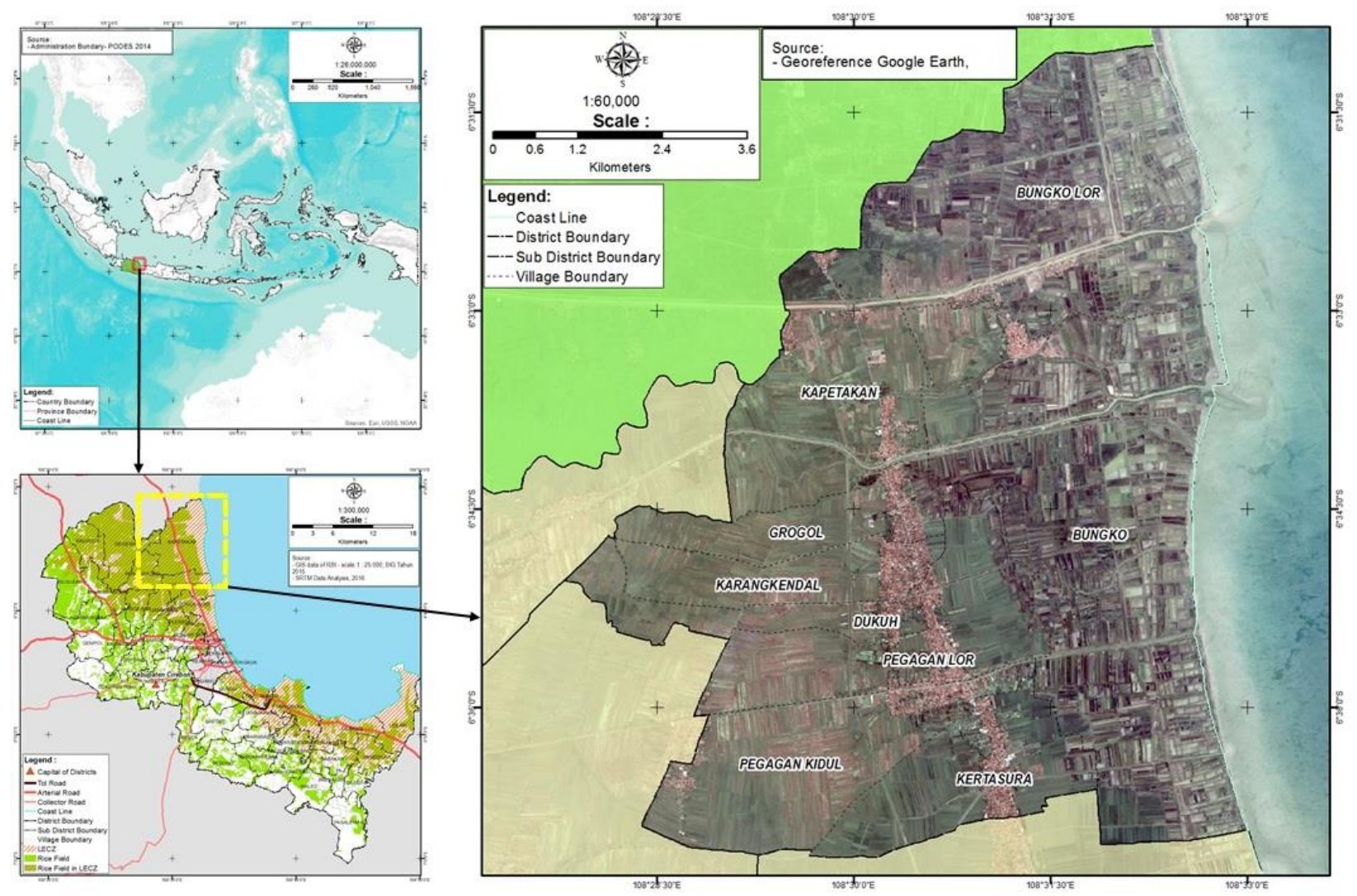

Fg. 1 Orientation of Study Area in Cirebon Regency Source: modified from BIG (2016)

\subsection{Research Method}

\subsubsection{Data Collection}

Mixed-methods by combining qualitative and quantitative data was employed in this study. The data used were official data released by the government as well as supported by literature review as secondary data, and in-depth interviews for primary data. The related variables as a scope of this study to analyze the livelihood of farmers to drought have been developed (Table 1).

Table 1. Research Variables

\begin{tabular}{|c|c|c|}
\hline Variable & Operational Definition of Variables & Data Sources \\
\hline Rainfall (mm) & $\begin{array}{l}\text { The amount of rainwater that falls on the soil } \\
\text { surface for a certain period }\end{array}$ & $\begin{array}{l}\text { Meteorological, } \\
\text { Climatological, and } \\
\text { Geophysical Agency }\end{array}$ \\
\hline $\begin{array}{l}\text { Rice production } \\
\text { (ton) }\end{array}$ & $\begin{array}{l}\text { The amount of rice harvest in the form of dry } \\
\text { grain harvest }\end{array}$ & Statistical Agency \\
\hline $\begin{array}{l}\text { Frequency of } \\
\text { harvest }\end{array}$ & The amount of rice harvest in one year & Interview \\
\hline $\begin{array}{l}\text { Farmers' } \\
\text { income }\end{array}$ & $\begin{array}{l}\text { The amount of money generated from } \\
\text { agriculture }\end{array}$ & $\begin{array}{l}\text { Statistical Agency and } \\
\text { Village Offices in } \\
\text { Kapetakan Sub- } \\
\text { district }\end{array}$ \\
\hline
\end{tabular}


Nila A. H. Pratiwi, Mahawan Karuniasa, Djoko S. A. Suroso | ASEAN Journal of Community Engagement | Volume 2, Number 1, 2018

\begin{tabular}{lll}
\hline \multicolumn{1}{c}{ Variable } & \multicolumn{1}{c}{ Operational Definition of Variables } & \multicolumn{1}{c}{ Data Sources } \\
\hline Crop insurance & The number of farmers that join crop insurance & $\begin{array}{l}\text { Village Offices in } \\
\text { Kapetakan Sub- } \\
\text { district }\end{array}$ \\
\hline $\begin{array}{l}\text { Self- } \\
\text { organization }\end{array}$ & $\begin{array}{l}\text { Networking ability of farmers and related } \\
\text { stakeholders to be able to determine the option } \\
\text { of anticipatory and proactive actions in } \\
\text { addressing the impacts of extreme weather } \\
\text { event }\end{array}$ & Interview \\
\hline
\end{tabular}

The systematic literature review was conducted through reviewing research publications related to livelihood resilience as the basic concept of this study, specifically about crop insurance and self-organization as the scope of this study. The literature review results were further utilized in the analysis for result and discussion in this paper.

Additionally, in-depth interviews were conducted through face-to-face interviews. Informants for interview targets were key stakeholders related to the issues of climate change and its impacts on agriculture. The key stakeholders consisted of (i) local government agencies, including the Agricultural Agency and Kapetakan Sub-district Office; and (ii) local community leaders such as Chairman of the Joint Farmer Group (GAPOKTAN) and agricultural extension workers. The information gathered from each key stakeholder can be seen on the Table 2 .

Table 2. Type of Information for Interview

\begin{tabular}{cll}
\hline No. & \multicolumn{1}{c}{ Key Informants } & \multicolumn{1}{c}{ Type of Information } \\
\hline 1. & Local government agencies & \\
\hline 1.a & Agricultural Agency & $\begin{array}{l}\text { Drought threat for rice farmers, agricultural } \\
\text { programs related to livelihood adaptation } \\
\text { including crop insurance mechanism. }\end{array}$ \\
\hline 1.b & Kapetakan Sub-district Office & $\begin{array}{l}\text { Drought threat for rice farmers as well as how to } \\
\text { respond to those impacts, crop insurance } \\
\text { implementation, network development to rice } \\
\text { farmers. }\end{array}$ \\
\hline 2. & Local community leaders & Rice farmers' respond to crop failure because of \\
& Group (GAPOKTAN) & Chairman of the Joint Farmer \\
& & $\begin{array}{l}\text { constraint of crop insurance ownership for rice } \\
\text { farmers, benefit of farmers join in farmer groups. }\end{array}$ \\
\hline 2.b & Agricultural extension worker & Benefit of agricultural extension for rice farmers.
\end{tabular}

\subsubsection{Data Analysis}

Quantitative method used was descriptive statistics among others to analyze the impact of drought on rice production and farmers' income. Most data for this analysis are secondary data, such as rainfall and rice production, which were then processed with a certain calculation to produce a value expressed with a mean or percentage. Results of data processing are presented in the form of graphs or diagrams. Quantitative method was also 
used to assess the intensity of drought under rainfall conditions. Based on Meteorological, Climatological, and Geophysical Agency/ BMKG (2015), the first indication to know the occurrence of drought can be done through the calculation of meteorological drought rate with the intensity of drought (Table 3).

Table 3. Classification of drought intensity

\begin{tabular}{cc}
\hline Percentage from normal rainfall condition & Classification \\
\hline $\mathbf{7 0 - 8 5 \%}$ & Dry \\
\hline $\mathbf{5 0 - 7 0 \%}$ & Very dry \\
\hline$<\mathbf{5 0 \%}$ & Extremely dry \\
\hline
\end{tabular}

Source: Meteorological, Climatological, and Geophysical Agency (2015)

Meanwhile, qualitative method was used to describe systematically the findings of this study through interpretation of the quantitative data. In addition, this method was also utilized to explore the perception of key stakeholders on management and benefits of crop insurance in order to cope with loss of farmers' income. Obtaining information related to selforganization was also implicitly conducted during the interview. Furthermore, all the interview results were systematically described and compared with previous research derived from the literature review to formulate how self-organization can enhance livelihood resilience through joining crop insurance to reduce financial risk due to extreme weather events. The existence of self-organization could be one method for community engagement to cope with climate change impact.

\section{Results and Discussion}

\subsection{Drought impact on farmers' livelihood}

Cirebon has experienced drought among others in 2012 and 2015 (BNPB, 2016b). Drought events can be observed from rainfall conditions that show a decrease (Fg. 2). In 2012, drought occurred in August-October with extremely dry intensity of 30-60\% from baseline conditions of 1980-2010. While in 2015, climate anomalies happened from June to November as a result of El Nino. The drought intensity was extremely dry with $0-3.2 \%$ in June to October due to no rain and $29.4 \%$ on November compared to baseline conditions of 1980-2010. Hereafter, rainfall increased due to La Nina that led to longer rainy season and higher rainfall in 2016. 
Nila A. H. Pratiwi, Mahawan Karuniasa, Djoko S. A. Suroso | ASEAN Journal of Community Engagement | Volume 2, Number 1, 2018

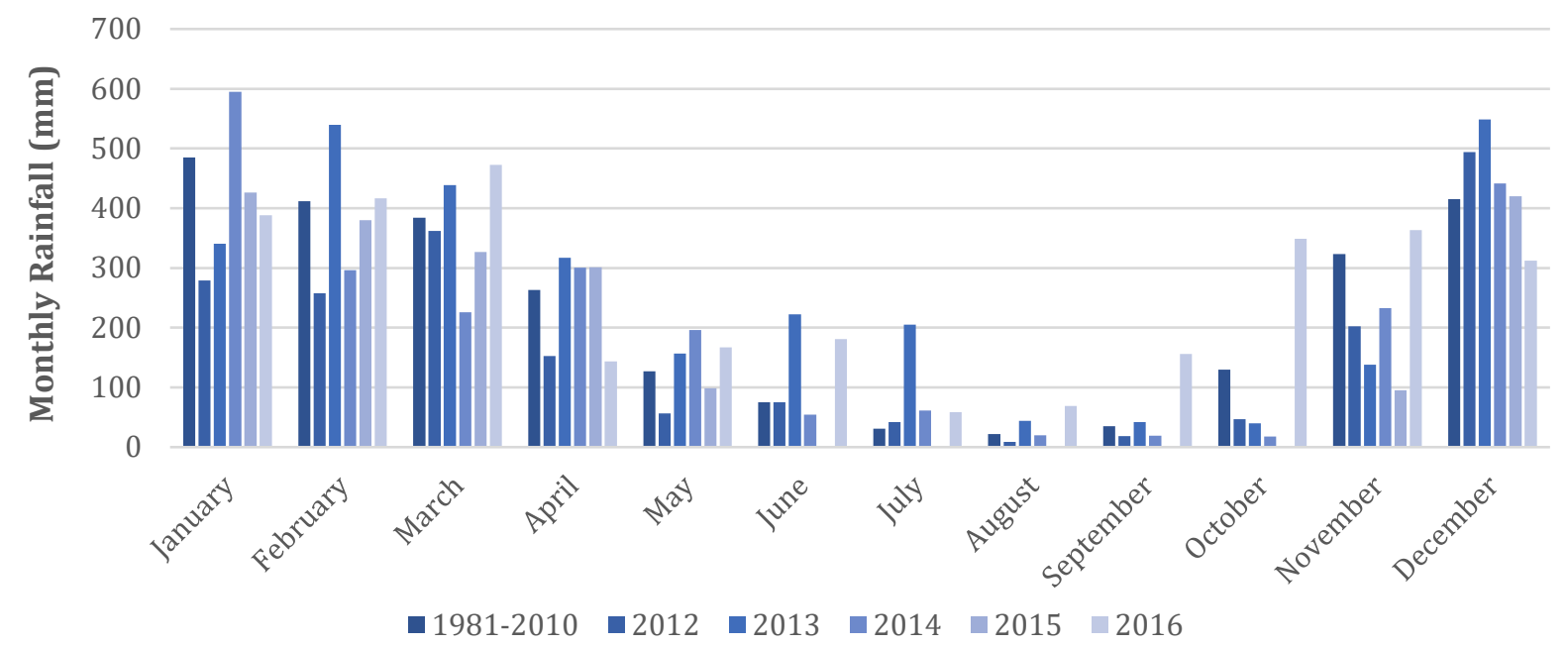

Fg. 2 Monthly rainfall in Cirebon Regency Source: Meteorological, Climatological, and Geophysical Agency

The Agricultural Agency of Cirebon explained that drought resulted in approximately 15,000 ha of rice fields $(26,7 \%$ of the total rice fields) could not be planted due to lack of water supply and implicated crop failure around 7,500 ha of rice fields $13,4 \%$ of the total rice fields) (Kabar Cirebon, 2015). This condition among others occurred in Kapetakan. Fg. 3 shows that rice production in Kapetakan decreased about 48\% in 2015 compared to 2014. Farmers experienced only one harvest period in March due to El Nino drought in the second cultivation period and significantly reduced their incomes (Pratiwi et al., 2017). At that time, irrigated rice fields in coastal areas did not acquire flow of water from upstream areas. Related to that, Abid et al. (2016a) argue that extreme weather events have a negative effect on agricultural production and rural livelihoods.

Based on interview results with several Chairman of GAPOKTAN, the average income of farmers in Kapetakan is approximately IDR 4.2 million for each cultivation period or IDR 8,4 million per year. However, drought has implications for the loss of farmers' income, whereas farmers still need to cover for their living cost until the next cultivation. Fg. 3 shows that farmers' income decreased almost 50\% in 2015 compared to 2014 due to drought. Farmers in Kapetakan depend heavily on agriculture to earn their living. In this regard, Abid et al. (2016a) argue that these conditions may limit the ability of farmers to adapt to climate change. According to Pratiwi et al. (2017), farmers in Kapetakan were only able to find alternative jobs in informal sector to increase their income because it does not require special skills nor higher education. Moreover, crop farmers in Indonesia generally borrow money from middlemen or moneylenders due to crop failure as an impact of extreme weather events (Boer, 2012). According to Shah et al. (2013), extreme weather events can have direct implications for creating unsustainable livelihoods and/or reducing the livelihood options of rural poor. 


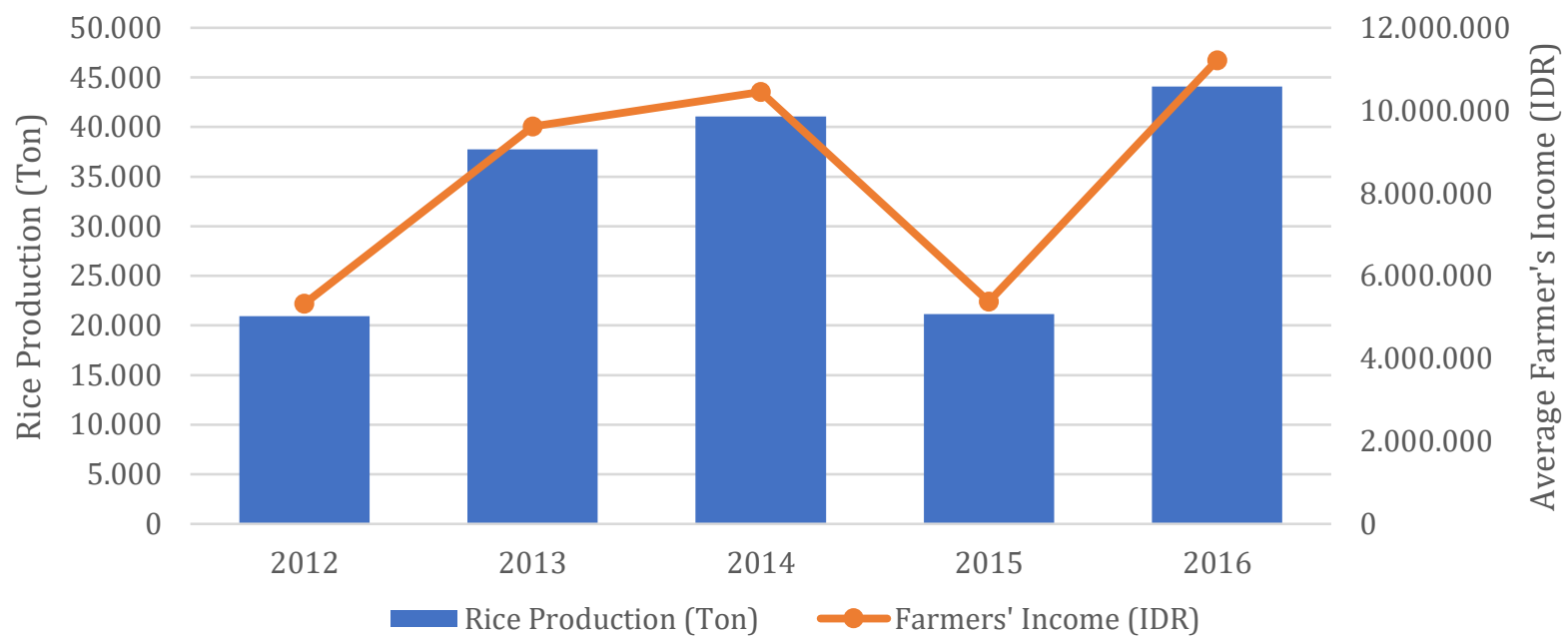

Fg. 3 Annual rice production and farmers' income

Source: modified from Statistical Agency/ BPS of Cirebon Regency (2013 and 2017) and interview results

\subsection{Benefits of crop insurance to enhance livelihood resilience}

In Indonesia, agricultural insurance program is a mandate from Law No. 19/2013 and has been regulated in Regulation of Minister of Agriculture No. 40/Permentan/SR.230/7/2015. Based on this regulation, agricultural insurance, consisting of crop insurance and livestock insurance, is undertaken to protect farmers from loss of harvest due to natural disasters, attack of plant pest organisms, infectious animal disease epidemic, climate change impacts, and/or other types of risks. Therefore, crop insurance provides guarantees for crop damage due to drought which reduces the level of crop production. Farzaneh et al. (2017) also argue that crop insurance compensates farmers in case of crop failure even if all precautions have been taken by them.

The government also regulates the insurance premium that should be paid by farmers, which is IDR 36,000 per hectare per cultivation period. This premium has already been subsidized by the government as much as IDR 144,000 per hectare per cultivation period. Hence the total of insurance premium is IDR 180,000 calculated from the cost of production for a one-time cultivation. Every member of farmer groups could obtain the premium subsidies. The crop insurance owners will receive compensation with amount of IDR 6 million per hectare per cultivation period in case of crop damage or crop failure.

Fg. 4 illustrates the assumption of Kapetakan farmers' incomes with crop insurance higher than without crop insurance in case of drought. The calculation of potential income obtained from the average income of farmers and crop insurance claim. The crop insurance claim could support farmers to meet their life necessities during drought as well as crop production capital for next cultivation. Dick and Wang (2010) also find that crop insurance can help farmers manage their financial losses from production risks. Thus, the crop insurance is very useful for farmers to cope with the impact of extreme weather events that cannot be predicted. 
Nila A. H. Pratiwi, Mahawan Karuniasa, Djoko S. A. Suroso | ASEAN Journal of Community Engagement | Volume 2, Number 1, 2018

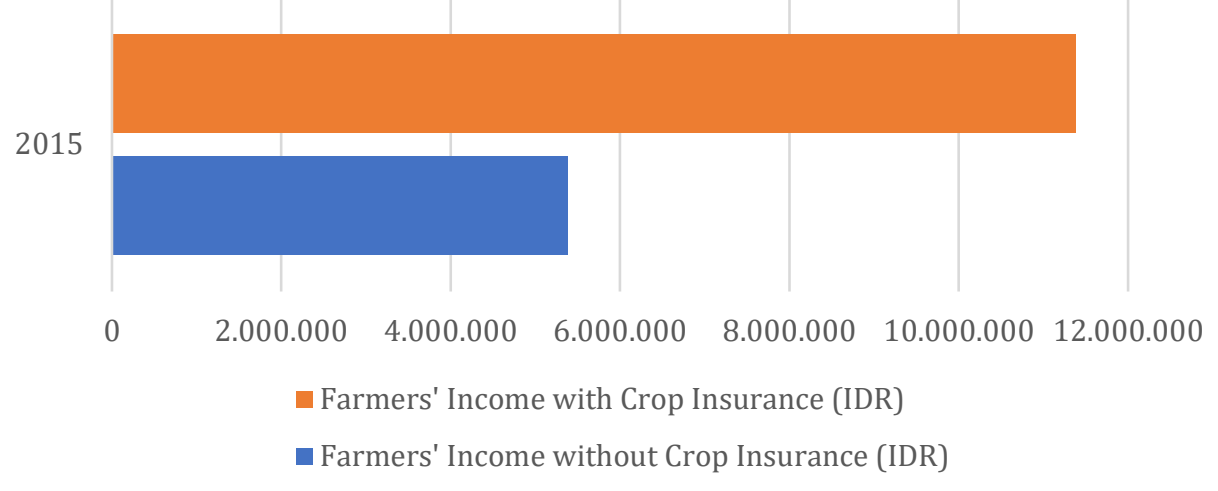

Fg. 4 Potential income of farmers in drought event, 2015

The farmers' income is actually enough to pay insurance premium since the insurance premium is quite cheap, only about IDR 36,000 per hectare per cultivation period (or $20 \%$ of total insurance premiums). However, there are still few farmers who have crop insurance during the El Nino's drought in 2015 as well as currently because the socialization of crop insurance only started from 2016. The Chairman of GAPOKTAN and agricultural extension worker argue that most farmers have not received agricultural insurance information, and farmers also think that it is not worth having insurance because the quality of rice production was not good and they only manage less than one hectare of rice fields. Farzaneh et al. (2017) reveal that farmers often view insurance as an unnecessary cost instead of an investment to reduce future risks, especially given the size of their small holdings of rice fields even though crop insurance can help farmers to stabilize their income (Marza et al., 2015). Sihem (2017) suggests that economic and institutional policies should be integrated with the development of crop insurance, such as agricultural development and crop management policies. For instance, crop insurance owners are encouraged to attempt new cultivation technologies, such as utilizing more dry and higher yielding varieties for farming to ensure the survival of crop although the price is higher (Boer, 2012).

\subsection{Self-organization to enhance livelihood resilience}

Government has a great role in regulating the development of agricultural system in Indonesia. In terms of agricultural system, crop insurance program contributes to strengthen national food security. Generally, self-organization in agricultural system has been created mandatory and bureaucratically. Besides the government at national to local level, agricultural insurance mechanism also involves some parties, including community and private sector to approach utilization of crop insurance.

Socialization of crop insurance for farmers still continues with the expectation that all farmers have this insurance. Increased awareness about crop insurance should encourage self-organization in each farmer group. In Kapetakan, it is found that farmer groups only interact and cooperate with other farmer groups within one organization called GAPOKTAN at the village level. Through GAPOKTAN, each farmer group can access various agricultural needs, such as seeds, fertilizers, agricultural tools and machinery, market price information, agribusiness training, and also agricultural insurance. While farmers have received a lot of information from the organization, social interactions in this small scope can be categorized 
as homogeneous communities that tend to have the same perception and knowledge related to agricultural practices.

The government or other stakeholders need to encourage farmer groups to expand their networks to other areas to improve the learning capacity of agricultural practices, including ownership of crop insurance in the face of extreme weather events. Utaranakorn and Yasunobu (2016) argue that the improvement of farmers' managerial skills can be gained from the learning and sharing of information or ideas among farmers from other groups and/or communities in the wider network. Accordingly, the various benefits of agricultural insurance ownership can be understood from interaction or cooperation within these networks. In addition, the owners of crop insurance can also gain an understanding of financial management in utilizing the insurance claims for household necessities, farm capital, savings, and others. Thus, farmers will have a self-organized manner in managing their finances during extreme weather events. Euler and Heldt (2018) found that selforganization can make individuals have the knowledge, ability, and more competence to create their own living conditions, in this case is farmer financial management.

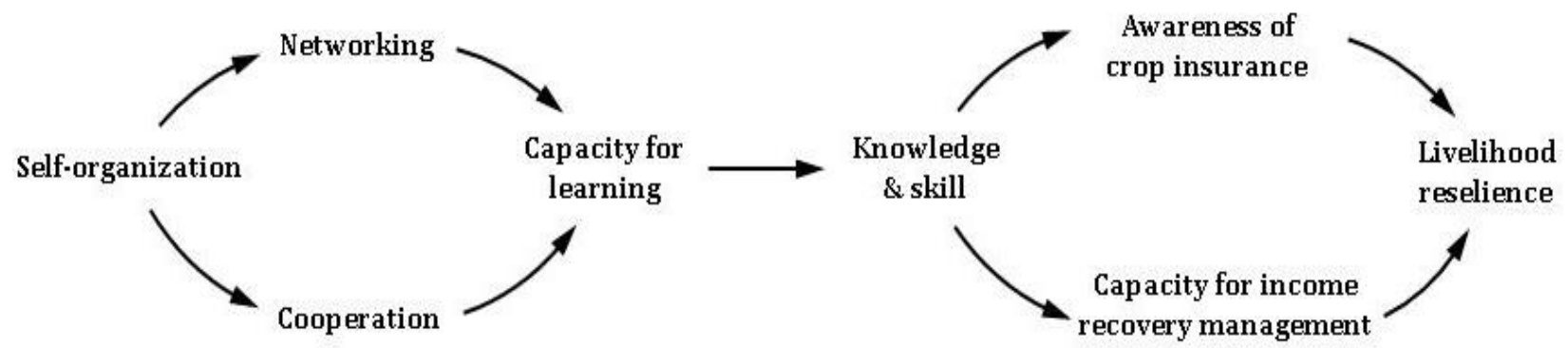

Fg. 5 Self-organization to encourage the role of crop insurance towards farmers' livelihood resilience

\section{Conclusion}

Climate variability and change that affect extreme weather events have resulted in more frequent droughts in Indonesia, including Cirebon Regency. The study reveals that El Nino's drought in 2015 reduced rice production and farmers' income more significantly compared to 2014. Based on crop insurance program of the Ministry of Agriculture, farmers with crop insurance are entitled to obtain compensation of IDR 6 million per hectare in case of crop failure for each cultivation period by paying an insurance premium of IDR 36,000 per hectare per cultivation period. In this case, crop insurance can serve as a financial capital that contributes to enhance livelihood resilience as it can stabilize farmers' income during extreme weather events. However, many farmers do not have crop insurance and they can only find other jobs in informal sector or debt during drought to meet their life necessities and next farm production needs. Therefore, they need to gain awareness of the vulnerability and risks of crops to extreme weather events and the benefits of crop insurance.

The crop insurance is important to secure farmers' income so that self-organization needs to be strengthened. Self-organization in crop insurance management that involves government, private and community has been formed mandatorily and bureaucratically by the central government. However, this study finds that self-organization related to the network capacity of farmers needs to be encouraged in order to interact, cooperate, and exchange learning with other organizations outside the region. Thus, the knowledge and skills of farmers on the benefits of crop insurance and how to manage their finances will 
Nila A. H. Pratiwi, Mahawan Karuniasa, Djoko S. A. Suroso | ASEAN Journal of Community Engagement | Volume 2, Number 1, 2018

increase. This condition will contribute to enhance livelihood resilience of farmers to recover from extreme weather events.

Related to crop insurance development, the government needs to develop index-based climate insurance in order to better protect the livelihood of farmers. Hence, insurance claims will be assessed based on climate index instead of crop failure. It might increase the courage of farmers to use climate-resilient technologies for agricultural since the risk of crops has been covered by insurance.

\section{References}

Abid, M., Schneider, U. A., \& Scheffran, J. (2016a). Adaptation to climate change and its impacts on food productivity and crop income: Perspectives of farmers in rural Pakistan. Journal of Rural Studies, 47, 254-266.

Abid, M., Schilling, J., Scheffran, J., \& Zulfiqar, F. (2016b). Climate change vulnerability, adaptation and risk perceptions at farm level in Punjab, Pakistan. Science of the Total Environment, 547, 447-460.

BAPPENAS. (2010). Indonesia climate change sectoral roadmap: Synthesis report. Jakarta: BAPPENAS.

Bhuvaneswari, K., Geethalakshmi, V., Lakshmanan, A., Srinivasan, R., \& Sekhar, N. U. (2013). The impact of El Nino/ Southern Oscillation on hydrology and rice productivity in the Cauvery Basin, India: Application of the soil and water assessment tool. Weather and Climate Extremes, 2, 39-47.

BIG. (2016). Data spasial peta IGD 25k-penutup lahan, (Spatial data map of IGD 25k-land cover). Retrieved September 28, 2016, from http://tanahair.indonesia.go.id/home/download_rbi/25k_penutuplahan.html

BMKG. (2015). Buku informasi peta kekeringan dengan metode SPI Propinsi Banten dan DKI Jakarta bulan Oktober 2015. Tangerang Selatan: Stasiun Klimatologi Pondok Betung.

BNPB. (2016a). Risiko bencana Indonesia, (Indonesia's disaster risk). Jakarta: BNPB.

BNPB. (2016b). Kejadian bencana kekeringan di wilayah Provinsi Jawa Barat, (Drought incident in West Java Province). In Data dan Informasi Bencana Indonesia. Retrieved September 25, 2016, from http://dibi.bnpb.go.id

Boer, R. (2012). Asuransi iklim sebagai jaminan perlindungan ketahanan petani terhadap perubahan iklim, (Climate insurance as a guarantee of farmers resilience protection against climate change). Prosiding Widyakarya Nasional Pangan dan Gizi 10: Pemantapan Ketahanan Pangan dan Perbaikan Gizi Berbasis Kemandirian dan Kearifan Lokal, 14 pp.

BPS. (2014). Village Potential Statistics of Indonesia. Jakarta: BPS.

BPS Kabupaten Cirebon. (2013). Cirebon regency in figure 2013. Kabupaten Cirebon: BPS Kabupaten Cirebon.

BPS Kabupaten Cirebon. (2017). Cirebon regency in figure 2017. Kabupaten Cirebon: BPS Kabupaten Cirebon.

Brocklesby, M. A., \& Fisher, E. (2003). Community development in sustainable livelihood approaches: An introduction. Community Development Journal, 38(3), 185-198.

Capa-Morocho, M., Rodríguez-Fonseca, B. \& Ruiz-Ramos, M. (2014). Crop yield as a bioclimatic index of El Nino impact in Europe: Crop forecast implications. Agricultural and Forest Meteorology, 198-199, 42-52.

DFID. (1999). Sustainable livelihoods guidance sheets. London: DFID. 
Dick, W. J. A., \& Wang, W. (2010). Government interventions in agricultural insurance. Agriculture and Agricultural Science Procedia, 1, 4-12.

Elasha, B. O., Elhassan, N. G., Ahmed, H., \& Zakieldin, S. (2005). Sustainable livelihood approach for assessing community resilience to climate change: Case studies from Sudan. AIACC Working Paper, 17.

Euler, J., \& Heldt, S. (2018). From information to participation and self-organization: Visions for European river basin management. Science of the Total Environment, 621, 905-914.

Farzaneh, M., Allahyari, M. S., Damalas, C. A., Seidavi, A. (2017). Crop insurance as a risk management tool in agriculture: The case of silk farmers in northern Iran. Land Use Policy, 64, 225-232.

Heylighen, F. (2001). The science of selforganization and adaptivity. In: L. D. Kiel (Ed.) Knowledge management, organizational intelligence and learning, and complexity (pp. 253-280). Oxford: Eolss Publishers.

IPCC. (2012). Managing the risks of extreme events and disasters to advance climate change adaptation: Summary for policymakers. [Field, C.B., V. Barros, T.F. Stocker, D. Qin, D.J. Dokken, K.L. Ebi, M.D. Mastrandrea, K.J. Mach, G.-K. Plattner, S.K. Allen, M. Tignor, \& P.M. Midgley (eds.)]. A Special Report of Working Groups I and II of the Intergovernmental Panel on Climate Change. Cambridge University Press, Cambridge, UK, and New York, NY, USA, pp. 1-19.

Irawan, B. (2013). Dampak El Nino dan La Nina terhadap produksi padi dan palawija. In H. Soeparno, E. Pasandaran, M. Syarwani, A. Dariah, S. M. Pasaribu, N. S. Saad (Eds.), (The impact of El Nino and La Nina on rice and palawija production). (Politik Pembangunan Pertanian Menghadapi Perubahan Iklim) (pp. 29-51). Bogor: Badan Penelitian dan Pengembangan Pertanian.

Kabar Cirebon. (2015). Dampak kekeringan kian parah, (The impact of drought is getting worse). Retrieved October 13, 2016, from http://www.kabarcirebon.com/read/2015/08/dampak-kekeringan-kian-parah/

Ke, W., Qiao, Z., Kimura, S., \& Akter, S. (2015). Is the crop insurance program effective in China? Evidence from farmers analysis in five provinces. Journal of Integrative Agriculture, 14(10): 2109-2120.

Keshavarz, M., Maleksaeidi, H., \& Karami, E. (2017). Livelihood vulnerability to drought: A case of rural Iran. International Journal of Disaster Risk Reduction, 21, 223-230.

Khanal, U., Wilson, C., Hoang, V., \& Lee, B. (2018). Farmers' Adaptation to Climate Change, Its Determinants and Impacts on Rice Yield in Nepal. Journal of Ecological Economics, 144, 139-147.

Khayyati, M., \& Aazami, M. (2016). Drought impact assessment on rural livelihood systems in Iran. Journal of Ecological Indicators, 69, 850-858.

KLHK. (2017). SIDIK: Sistem Informasi Data Indeks Kerentanan, (SIDIK: Vulnerability Index Information System Data). Jakarta: Direktorat Adaptasi Perubahan Iklim, Direktorat Jenderal Pengendalian Perubahan Iklim, Kementerian Lingkungan Hidup dan Kehutanan.

Lunt, T., Jones, A. W., Mulhern, W. S., Lezaks, D. P. M., \& Jahn, M. M. (2016). Vulnerabilities to agricultural production shocks: An extreme, plausible scenario for assessment of risk for the insurance sector. Climate Risk Management, 13, 1-9.

Marza, B., Angelescu, C., \& Tindeche, C. (2015). Agricultural Insurances and Food Security: The New Climate Change Challenges. Procedia Economics and Finance, 27, 594-599. 
Nila A. H. Pratiwi, Mahawan Karuniasa, Djoko S. A. Suroso | ASEAN Journal of Community Engagement | Volume 2, Number 1, 2018

Milestad, R. (2003). Building farm resilience: challenges and prospects for organic farming. (Dissertation) Swedish University of Agricultural Sciences Uppsala. Retrieved January 29, 2018,

from http://citeseerx.ist.psu.edu/viewdoc/download?doi=10.1.1.457.255\&rep=rep1\&type=

Nakamura, N., Prabhakar, S.V. R. K., \& Ozawa, N. (2017). Agriculture insurance in Japan: Stakeholders' opinion on its effectiveness and ways forward. In S. V. R. K. Prabhakar, D. S. Solomon, A. Abu-Bakar, J. Cummins, J. J. Pereira, \& J. M. Pulhin (Eds.), Case studies in insurance effectiveness: Some insights into costs and benefits (pp. 41-60). Bangi, Malaysia: Southeast Asia Disaster Prevention Research Institute.

Pratiwi, N. A. H., Rahmawati, Y. D., \& Setiono, I. (2016). Mainstreaming gender in climate change adaptation: A case study from Cirebon, Indonesia. Asian Cities Climate Resilience Working Paper Series, 39, 50 pp.

Pratiwi, N. A. H., Rahmawati, Y. D., \& Setiono, I. (2017). Gender Equality in Climate Change Adaptation: A Case of Cirebon, Indonesia. The Indonesian Journal of Planning and Development, 2(2), 74-86.

Pulhin, J. M., Grefalda, L. B., Sabino, L. L., Predo, C. D., \& Prabhakar, S. V. R. K. (2017). Costs and benefits of government-supported agricultural insurance: Case studies from the Philippines. In S. V. R. K. Prabhakar, D. S. Solomon, A. Abu-Bakar, J. Cummins, J. J. Pereira, \& J. M. Pulhin (Eds.), Case studies in insurance effectiveness: Some insights into costs and benefits (pp. 61-71). Bangi, Malaysia: Southeast Asia Disaster Prevention Research Institute.

Rahut, D. B., \& Ali, A. (2017). Coping with climate change and its impact on productivity, income, and poverty: Evidence from the Himalayan region of Pakistan. International Journal of Disaster Risk Reduction, 24, 515-525.

Reed, M. S., Podesta, G., Fazey, I., Geeson, N., Hessel, R., Hubacek, K., Letson, D., Nainggolan, D., Prell, C., Rickenbach, M. G., Ritsema, C., Schwilch, G., Stringer, L. C. \& Thomas, A. D. (2013). Combining analytical frameworks to assess livelihood vulnerability to climate change and analyse adaptation options. Ecological Economics, 94, 66-77.

Setiyanto, A., \& Irawan, B. (2013). Prediksi pengaruh perubahan iklim terhadap produksi, konsumsi, dan harga komoditas pangan utama. In H. Soeparno, E. Pasandaran, M. Syarwani, A. Dariah, S. M. Pasaribu, N. S. Saad (Eds.), (Predicted effects of climate change on the production, consumption, and prices of major food commodities). Politik Pembangunan Pertanian Menghadapi Perubahan Iklim (52-80). Bogor: Badan Penelitian dan Pengembangan Pertanian.

Shah, K. U., Dulal, H. B., Johnson, C., \& Baptiste, A. (2013). Understanding livelihood vulnerability to climate change: Applying the livelihood vulnerability index in Trinidad and Tobago. Geoforum, 47, 125-137.

Sihem, E. (2017). Economic and socio-cultural determinants of agricultural insurance demand across countries. Journal of the Saudi Society of Agricultural Sciences.

Solomon, D. S., Prabhakar, S. V. R. K., \& Rao, G. S. (2017). Agriculture insurance in India: Stakeholder perspectives on associated costs and benefits. In S. V. R. K. Prabhakar, D. S. Solomon, A. Abu-Bakar, J. Cummins, J. J. Pereira, \& J. M. Pulhin (Eds.), Case studies in insurance effectiveness: Some insights into costs and benefits (pp. 23-39). Bangi, Malaysia: Southeast Asia Disaster Prevention Research Institute. 
Speranza, C. I., Wiesmann, U., \& Rist, S. (2014). An indicator framework for assessing livelihood resilience in the context of social-ecological dynamics. Global Environmental Change, 28, 109-119.

Tripathi, A., \& Mishra, A. K. (2017). Knowledge and passive adaptation to climate change: An example from Indian farmers. Climate Risk Management, 16, 195-207.

UNDP Indonesia. (2007). Sisi lain perubahan iklim: Mengapa Indonesia harus beradaptasi untuk melindungi rakyat miskinnya. Jakarta: UNDP Indonesia Country Office.

Utaranakorn, P., \& Yasunobu, K. (2016). The mutual influence of managerial ability and social networks of farmers on participation in an organic vegetable group in Khon Kaen Province, Thailand. Kasetsart Journal of Social Sciences, 37, 127-131.

Zikra, M., Suntoyo, \& Lukijanto. (2015). Climate change impacts on Indonesian coastal areas. Journal of Procedia Earth and Planetary Science, 14, 57-63. 